Aquaculture

November 2016, Volume 464, Pages 638-641

http://dx.doi.org/10.1016/j.aquaculture.2016.07.016

http://archimer.ifremer.fr/doc/00346/45690/

(c) 2016 Elsevier B.V. All rights reserved.

\title{
Seasonal variation of sperm quality in Pacific oyster (Crassostrea gigas)
}

\author{
Suquet Marc ${ }^{1,{ }^{*}}$, Malo Florent ${ }^{1,2}$, Quéau Isabelle ${ }^{1}$, Ratiskol Dominique ${ }^{1}$, Quéré Claudie ${ }^{3}$, \\ Le Grand Jacqueline ${ }^{1}$, Fauvel Christian ${ }^{4}$
}

${ }^{1}$ Ifremer, UMR 6539, PFOM Department, Station Expérimentale d'Argenton, Argenton, France

2 Ifremer, Délégation de Nouvelle Calédonie, Nouméa, France

3 Ifremer, UMR 6539, PFOM Department, Plouzané, Argenton, France

${ }^{4}$ Ifremer, UMR 5119, Marbec, Palavas, France

*Corresponding author : Marc Suquet, email address : marc.suquet@ifremer.fr

\begin{abstract}
:
Seasonal changes of sperm quality which can affect sperm biological parameters throughout the breeding period, have been little studied in mollusc species. Controlling gamete quality would aid the management of gametes in hatcheries and the development of selection programs. The aim of the present study was to describe the changes in sperm quality of wild Pacific oysters through the spawning season by comparing sperm parameters at the beginning (May), middle (July) and end (October) of this period using a panel of bio-descriptors. These parameters were studied over the 2014 breeding season based on shed sperm collected after serotonin injection of wild breeders. A significantly higher percentage of motile sperm was observed at the end of the spawning season $(+78 \%$ relative to the value observed at the beginning) althought a lower total number of spermatozoa was collected (-59\%). The mean condition index of oysters, however, was no different between the three sampling dates. For intratesticular sperm, the increase of the percentage of motile sperm and Velocity of the Average Path (VAP) in relation to time post activation was not significantly different among sperm sampling periods, suggesting that the kinetic of the sperm maturation process was similar. Furthermore, the mean VAP observed on shed sperm did not change through the spawning season. The sub-continuous gametogenesis of Pacific oyster can help to explain why only limited consequences of sperm ageing are observed in this species. Furthermore, the effects of sperm ageing may depend on the annual reproductive pattern of Pacific oyster. Statement of relevance This study showed the effect of sperm ageing on sperm quality parameters. This knowledge is useful for aquaculture and would support the recent trends of mollusc farming, allowing a better management of the gametes in hatchery.
\end{abstract}




\section{Highlights}

- Changes in sperm quality throughout the spawning period have been little studied in molluscs. At the end of the season, changes were only observed for sperm number and the percentage of motile cells. The gametogenesis of Pacific oyster may explain the limited consequences of sperm ageing.

- Annual changes in reproductive pattern may modify the consequences of sperm ageing.

Keywords : Crassostrea gigas, Sperm quality, Sperm ageing, Season, Motility

\section{Introduction}

Seasonal changes of sperm quality, also known sperm ageing or sperm senescence, were reviewed in aquatic species by Rana (1995), Rurangwa et al. (2004), Alavi et al. (2008) and Cabrita et al. (2009), , showing they can affect sperm biological parameters throughout the breeding period. In marine fish species, changes in sperm quality through the spawning season were first described in seabass (Dicentrarchus labrax), highlighting a decrease ofsperm movement duration and sperm storage capacity at the end of the reproductive period (Billard et al., 1977). A later study on the same species showed a decline in several biomarkers at the end of the reproductive period, including sperm concentration, intracellular 
ATP content and percentage of motile spermatozoa, but also in fertilization, short term storage and cryopreservation capacities (Dreanno et al., 1999). A similar decrease in sperm quality through the reproductive season was also observed in Atlantic halibut (Hippoglossus hippoglossus; Methven and Crim, 1991), Atlantic cod (Gadus morhua; Rouxel et al., 2008), and sole (Solea senegalensis; Beirao et al., 2011).

In invertebrates, knowledge and control of gamete quality are still incomplete (Bobe and Labbé, 2010) because of the high fecundity of the breeders and the frequent use of spat collected from the wild. Greenlip abalone (Haliotis laevigata) sperm collected during the intermediate part of the reproductive period was of higher quality, in terms of motility, fertilization capacity, morphological integrity and post-thawing survival, than samples collected at the beginning or the end of the season (Liu et al., 2015). Improving our control of gamete quality would support the recent trends observed in mollusc farming such as breeder selection and creation of special lines such as tetraploids.

In oyster species, few studies have yet examined the changes that occur in sperm quality as the reproductive period progresses. Pacific oysters with highly motile sperm (>70\% motile spermatozoa) were observed from February to October (Cardona-Costa et al., 2010), but this result was based on subjective estimates of sperm movement. Dong et al. (2005) suggested that sperm quality also had an effect on post-thawing survival. A sperm maturation process along the genital tract has been reported in Pacific oyster (Cosson et al., 2008), with spermatozoa acquiring their potential for motility during their transit along the genital ducts. Adding caffeine, a chemical belonging to the cAMP signalling process, accelerated sperm motility acquisition. However, possible changes in the sperm maturation process, in relation to the sampling period, have not finely been studied up to now. The study of seasonal variations of sperm quality is especially important in species with a long spermiation period, as described in Pacific oyster (Lango-Reynoso et al., 1999). 
The present paper aims to describe the seasonal variations of sperm quality in Pacific oyster collected from the wild, using a panel of bio-descriptors including the total number of sperm produced, kinetic of the sperm maturation process, intracellular ATP content and sperm movement characteristics.

\section{Material and methods}

\subsection{Oysters and sperm collection}

In 2014, Pacific oysters (mean weight \pm SEM: $105 \pm 10 \mathrm{~g}$ ) were collected in the Bay of Brest (Finistère, France, water temperature range: $8.5-20.5^{\circ} \mathrm{C}$; Pouvreau et al., 2016) at the beginning, middle and end of the spawning period, covering the time interval during which sperm can be collected from wild breeders. The oysters were then transferred to the Argenton experimental hatchery (Ifremer) and maintained in a 600-L raceway (SW: seawater $19^{\circ} \mathrm{C}$, salinity $34 \%$ ). Sperm quality parameters were measured on sampled oysters during the week following their capture.

For sperm maturation experiments, intratesticular sperm was sampled using a pipette and sperm movement was immediately triggered. For other biomarkers, males were treated with $50 \mu 1$ of a $10 \mathrm{mM}$ serotonin solution, diluted in seawater. Serotonin was injected into male gonads and oysters were transferred to 2-L beakers, filled with 0.5-L SW. Shed sperm was pipetted directly from the sperm plume, close to the gonopore, to collect concentrated samples, and stored at $4^{\circ} \mathrm{C}$ until use (method adapted from Suquet et al., 2013).

\subsection{Experimental design}


Oysters were processed at the beginning (21-26 May), middle (11-17 July) and end (814 October) of the spawning period. Oyster whole weight $(\mathrm{W})$ and flesh weight $(\mathrm{FW})$ were measured. After weighing, oyster condition index was calculated according to Royer et al. (2008): $\mathrm{CI}=(\mathrm{FW} / \mathrm{W})^{*} 100$.

In order to estimate the maturation process of intratesticular sperm, samples were activated by dilution in activating solution (AS: SW, Tris $20 \mathrm{mM}$ adjusted to $\mathrm{pH} 8.1,5 \mathrm{~g} \mathrm{~L}^{-1}$ BSA, with or without addition of $10 \mathrm{mM}$ caffeine; $1 \mu \mathrm{l}$ sperm transferred to $1.5 \mathrm{ml}$ AS). After activation, sperm samples of $12 \mu 1$ were transferred to Fast-Read 102 cells (Biosigma ${ }^{\circledR}$, Cona, Italy), and their movement was observed (Olympus BX51, $\times 10$ magnification) and recorded (Qicam fast, 60 frames $\mathrm{s}^{-1}$, 4s film duration) 1, 3, 5 and 10 minutes post sperm activation. Sperm movement characteristics (percentage of motile sperm and VAP: Velocity of the Average Path) were measured using a CASA plugin developed for Image $\mathbf{J}$ ( 2 to 3 films for each male), according to Suquet et al. (2016). Changes in both movement parameters in relation to time elapsed since activation were assessed by calculating the difference recorded between the highest and lowest values observed $(5 \mathrm{~min}$ and 1 min post sperm activation, respectively, as determined by ANOVA).

In serotonin-treated males, sperm movement was assessed immediately and at $2 \mathrm{~h}$ post activation, as described above (adding $10 \mathrm{mM}$ caffeine to the AS). Sperm density was assessed in duplicate samples using a Counter coulter multisizer 3 (Beckman), after $1: 2000$ dilution in seawater. Intracellular ATP content was assessed by bioluminescence (ATP lite kit, Perkin Elmer, triplicate samples) according to Boulais et al. (2015). Because of the low number of spermatozoa and the simultaneous presence of sperm and somatic cells, sperm intracellular ATP content could not be measured at the end of the reproductive period. Finally, the total number of spermatozoa collected from each male was calculated (sperm density $\times$ seawater volume) . 


\subsection{Statistical analysis}

Results are presented as mean \pm SEM ( $n=6$ males for each treatment). Data were log transformed except for the percentages of motile sperm which were arcsin square root transformed. Then, means were compared using one-, two- or three way ANOVA. When significant differences were observed $(\mathrm{P}<0.05)$, a Fisher a posteriori test was used to compare the means.

\section{Results}

The mean CI assessed on oysters was not significantly different $(\mathrm{P}=0.179)$ among the measurements made at the beginning $(14.2 \pm 1.1)$, middle $(17.8 \pm 1.8)$ and end $(17.4 \pm 2.0)$ of the spawning period.

In males from which intrastesticular samples were taken, no significant differences of the mean percentage of motile spermatozoa $(\mathrm{P}=0.209)$ or mean VAP $(\mathrm{P}=0.625)$ were observed in relation to sperm sampling period. Maximum values of motile sperm percentage and VAP were found at 5 minutes post activation, with results significantly higher than after just one minute (motile sperm: $\mathrm{P}=0.003$; VAP: $\mathrm{P}=0.001$; Fig. 1 ). The increase of both of these movement parameters between 1 and 5 minutes post activation, corresponding to the sperm maturation process, did not significantly differ among the sperm sampling periods $(\mathrm{P}=$ 0.505 for the percentage of motile sperm and $\mathrm{P}=0.081$ for VAP). Then, no significant differences were observed, both for the percentage of motile sperm $(\mathrm{P}=0.258)$ or VAP $(\mathrm{P}=$ 0.064), with the addition of $10 \mathrm{mM}$ caffeine, relative to the control. However, a significant 
interaction was found between sperm sampling period and the addition of caffeine in AS, both for the percentage of motile sperm $(\mathrm{P}=0.046)$ and VAP $(\mathrm{P}=0.031)$.

In serotonin-treated males, a significantly higher percentage of motile spermatozoa ( $\mathrm{P}$ $=0.025)$ was recorded in October, compared with May and July (Fig. 2A). Furthermore, the values observed immediately and $2 \mathrm{~h}$ post sperm activation did not differ $(\mathrm{P}=0.291)$. In contrast, although sperm VAP was not significantly different among the sampling dates $(\mathrm{P}=$ 0.280), a higher VAP was recorded immediately after sperm activation compared with results observed after $2 \mathrm{~h}(\mathrm{P}=0.005$; Fig. $2 \mathrm{~B})$. No significant differences of sperm intracellular ATP content were observed between the beginning (54.3 \pm 10.9 nmole $10^{-9}$ spermatozoa) and the middle $(51.0 \pm 6.4)$ of the spermiation season $(\mathrm{P}=0.778)$. Finally, compared to the midseason period, a significantly lower total number of spermatozoa was collected at the end of the reproductive period $(\mathrm{P}=0.040$; Fig. 3$)$.

\section{Discussion}

The present work describes seasonal variations of sperm quality in Pacific oyster. Sperm ageing, a phenomenon that progresses during the life of haploid sperm within testes, has already been described in mammals (Thibault, 1967), amphibians (Cabada, 1975) and fish (Rana, 1995). Aged sperm experience biochemical and morphological changes, functionally resulting in impaired cell motility, metabolism and fertilization capacity (Reinhardt, 2007).

Drastic effects of sperm senescence, leading to a decrease in most sperm quality traits at the end of the reproductive period, have been suggested to result from a discontinuous gametogenesis, as reported in seabass (Dreanno et al., 1999). In this type of gametogenesis, spermatozoa appear over a limited period of time and, because the spermiation period lasts several months, spermatozoa age as the reproductive period advances. In contrast, the 
consequences of sperm ageing appear moderate in aquatic species with continuous gametogenesis in which sperm production is continuous, e.g. guppy (Poecilia reticulata). This is also the case for species with sub-continuous gametogenesis in which several gametogenetic cycles may be initiated before the end of the previous one, e.g. common carp (Cyprinus carpio). During carp spermatogenesis, different reproductive cell stages are present simultaneously and no decline of the fertilization capacity is observed during the reproductive season of this species (Billard, 1986). Pacific oyster has also been suggested to have subcontinuous gametogenesis because different types of reproductive cells are present simultaneously in the testes (Fabioux, 2004), suggesting limited consequences of sperm ageing in this species.

In Pacific oyster, changes of sperm quality in relation to sampling date were observed in terms of a small number of sperm biological characteristics: at the end of the reproductive period, a lower total number of spermatozoa was observed (-59\%) but a higher percentage of motile spermatozoa $(+78 \%)$, compared with values recorded early in the reproductive season. Conversely, no significant changes in the condition index, sperm maturation capacity (described using the changes in the percentage of motile sperm and VAP), the percentage of motile spermatozoa and VAP recorded on shed sperm were observed in relation to the sampling date.

The reproductive pattern of Pacific oysters is observed annually in the Rade de Brest, where the breeders used for the present study were collected. In 2014, oyster spawning occurred continuously between August and October (Pouvreau et al., 2016). The reproductive pattern of oysters observed in 2015 was very different, as a peak spawning event was recorded between 15 and 31 August during which the entire stock of Pacific oysters spawned. In 2015 , a $33 \%$ decrease in the percentage of motile spermatozoa and a $75 \%$ decrease in the survival of cryopreserved spermatozoa were recorded in October, compared with earlier 
measurements made in May and July (Malo, unpublished results), indicating a low quality of these gametes. All these observations suggest that the effects of sperm ageing may depend on the annual reproductive pattern of Pacific oyster, which can differ among years. This could modify the management of Pacific oyster sperm in aquaculture when breeders are collected in the wild. However, such changes in the reproductive pattern of wild Pacific oysters remain difficult to predict because oyster spawning is the result of a complex interaction between several parameters, including water temperature, phytoplanktonic blooms and the level of the tide (Bernard, 2011).

In conclusion, moderate seasonal changes in sperm quality were observed in Pacific oyster. However, annual changes in reproductive pattern may modify the consequences of sperm ageing in this species.

\section{Acknowledgements}

The authors thank Stephane Pouvreau (Ifremer) for fruitful discussions on oyster reproduction. Many thanks to Helen McCombie for corrections of the English. Financial support was provided by the CRB-anim infrastructure project, ANR-11-INBS-0003, funded by the French National Research Agency within the framework of the "Investing for the Future program".

\section{References}

Alavi, S.M. H., Linhart, O., Coward, K., Rodina, M., 2008. Fish spermatology: Implications for aquaculture management. In: Alavi, S.M.H., Cosson, J., Rafiee, G. (Eds.), Fish spermatology, Alpha science, Oxford, pp. 397-460. 
Beirao, J., Soares, F., Herraez, M.P., Dinis, M.T., Cabrita, E., 2011. Changes in Solea senegalensis sperm quality through the year. Anim. Reprod. Sci. 126, 122-129.

Bernard, I., 2011. Ecologie de la reproduction de l'huître creuse, Crassostrea gigas, sur les côtes atlantiques françaises. Vers une explication de la variabilité du captage. Thèse, Univ. La Rochelle, 196pp. http://archimer.ifremer.fr/doc/00040/15155/12492.pdf

Billard, R., 1986. Spermatogenesis and spermatology of some teleost fish species. Reprod. Nut. Develop. 26, 877-920.

Billard, R., Dupont, J., Barnabé, G., 1977. Diminution de la motilité et de la durée de conservation du sperme de Dicentrarchus labrax L. (Poisson, Téléostéen) pendant la période de spermiation. Aquaculture 11,363-367.

Bobe, J., Labbé, C., 2010. Egg and sperm quality. Gen. Comp. Endocrinol. 165, 535-548.

Boulais, M., Soudant, P., Le Goïc, N., Quéré, C., Boudry, P., Suquet, M., 2015. Involvement of mitochondrial activity and OXPHOS in ATP synthesis during the motility phase of spermatozoa in the Pacific oyster, Crassostrea gigas. Biol. Reprod. 93, 118, 1-7.

Cabada, M.O., 1975. Seasonal variations in the fertilizing capacity of Bufo arenarum (Amphibia anura) spermatozoa. Exp. 31, 174-175.

Cabrita, E., Robles, V., Herraez, P., 2009. Sperm quality assessment. In Cabrita, E., Robles, V., Herraez, P. (Eds.), Methods in reproductive aquaculture, CRC Press, Boca Raton, pp. 93-142.

Cardona-Costa, J., Garcia-Ximenez, F., Espinos, F.J., 2010. Seasonal evolution of gonadal maturation, gamete quality, and fertilizability of Pacific oyster (Crassostrea gigas) on the Western Mediterranean coast. J. Shellfish Res. 29, 833-837.

Cosson, J., Faure, C., Devauchelle, N., Suquet, M., 2008. Activation of oyster (Crassostrea 
gigas) sperm motility. In: Physiomar 08, 1 - 4 September 2008, Brest, France, p. 24. http://archimer.ifremer.fr/doc/2008/acte-4600.pdf.

Dong, Q., Huang, C., Eudeline, B., Tiersch, T.R., 2005. Systematic factor optimization for cryopreservation of shipped sperm samples of diploid Pacific oysters, Crassostrea gigas. Cryobiology 51, 176-195.

Dreanno, C., Suquet, M., Fauvel, C., Le Coz, J.R., Dorange, G., Quemener, L., Billard, R., 1999. Effect of the aging process on the quality of sea bass (Dicentrarchus labrax) semen. J. Appl. Ichthyol. 15, 176-180.

Fabioux C., 2004. Origine et développement des cellules germinales chez l'huître Crassostrea gigas: Intérêt pour le contrôle de la reproduction en écloserie. Thèse, Univ. Bretagne Occidentale, Brest, France, 199pp. http://archimer.ifremer.fr/doc/2004/these-1380.pdf Lango-Reynoso, F., Devauchelle, N., Le Pennec, M., Hatt, P.J., 1999. Elements of reproductive strategy in oysters, Crassostrea gigas, from the « Rade de Brest», France. Inv. Reprod. Develop. 36, 141-144.

Liu, Y., Li, X., Xu, T., Robinson, N., Qin, J., 2015. Effects of broodstock age and sperm collection time over a natural spawning period on sperm cryopreservation in farmed greenlip abalone (Haliotis laevigata). J. World Aquac. Soc. 46, 665-671

Methven, D.A., Crim, L.W., 1991. Seasonal changes in spermatocrit, plasma sex steroids, and motility of sperm from Atlantic halibut (Hippoglossus hippoglossus). In: Scott, A.P., Sumpter, J.P., Kime, D.E., Rolfe, M.S. (Eds.), Proc. of the Fourth Int. Symp. on the Reproductive Physiology of fish, FishSymp91, Sheffield, p. 170.

Pouvreau, S., Maurer, D., Auby, I., Lagarde, F., Le Gall, P., Cochet, H., Bouquet A.L., Geay, A., Mille, D., 2016. Velyger Database: The oyster larvae monitoring French project. http://wwz.ifremer.fr/velyger/Acces-aux-Donnees/Rade-de-Brest/Maturation, accessed 4 February 2016. 
Rana, K., 1995. Preservation of gametes. In: Bromage, N.R., Roberts, R.J. (Eds.), Broodstock management and egg and larval quality, Blackwell Science, London, U.K., pp. 53-93.

Reinhardt, K., 2007. Evolutionary consequences of sperm cell aging. Quart. Rev. Biol. 82, 375-393.

Rouxel, C., Suquet, M., Cosson, J., Severe, A., Quemener, L., Fauvel, C., 2008. Changes in Atlantic cod (Gadus morhua L.) sperm quality during the spawning season. Aquac. Res. 39, 434-440.

Royer, J., Seguineau, C., Park, K., Pouvreau, S., Choi, K.S., Costil, K., 2008. Gametogenetic cycle and reproductive effort assessed by two methods in 3 age classes of Pacific oysters, Crassostrea gigas, reared in Normandy. Aquaculture 277, 313-320.

Rurangwa, E., Kime, D.E., Ollevier, F., Nash, J.P., 2004. The measurement of sperm motility and factors affecting sperm quality in cultured fish. Aquaculture 234, 1-28.

Suquet, M., Quéré, C., Mingant, C., Lebrun, L., Ratiskol, D., Miner, P., Cosson, J., 2013. Effect of sampling location, release technique and time after activation on the movement characteristics of scallop (Pecten maximus) sperm. Aquat. Living Resour. $26,215-220$.

Suquet, M., Malo, F., Quéré, C., Ledu, C., Le Grand, J , Benabdelmouna, A., 2016. Gamete quality in triploid Pacific oyster (Crassostrea gigas). Aquaculture 451, 11-15.

Thibault, C., 1967. Analyse comparée de la fécondation et de ses anomalies chez la brebis, la vache et la lapine. Ann. Biol. Anim. Bioch. Biophys. 7, 5-23. 


\section{Figure captions}

Fig. 1. Effect of sampling period on the sperm maturation process of Pacific oysters, as measured by changes in the percentage of motile sperm and velocity of the average path (VAP) in relation to time post activation, with and without $10 \mathrm{mM}$ caffeine (datapoints are mean \pm SEM; $n=6$ oysters $)$.

Fig. 2. Effect of sampling period on sperm movement characteristics of Pacific oysters: A) Percentage of motile sperm, B) Sperm velocity of the average path: VAP (datapoints are mean $\pm S E M ; n=6$ oysters; different letters indicate significantly different results).

Fig. 3. Effect of sampling period on the total number of collected spermatozoa, in Pacific oysters (datapoints are mean $\pm \mathrm{SEM} ; \mathrm{n}=6$ oysters; different letters indicate significantly different results). 

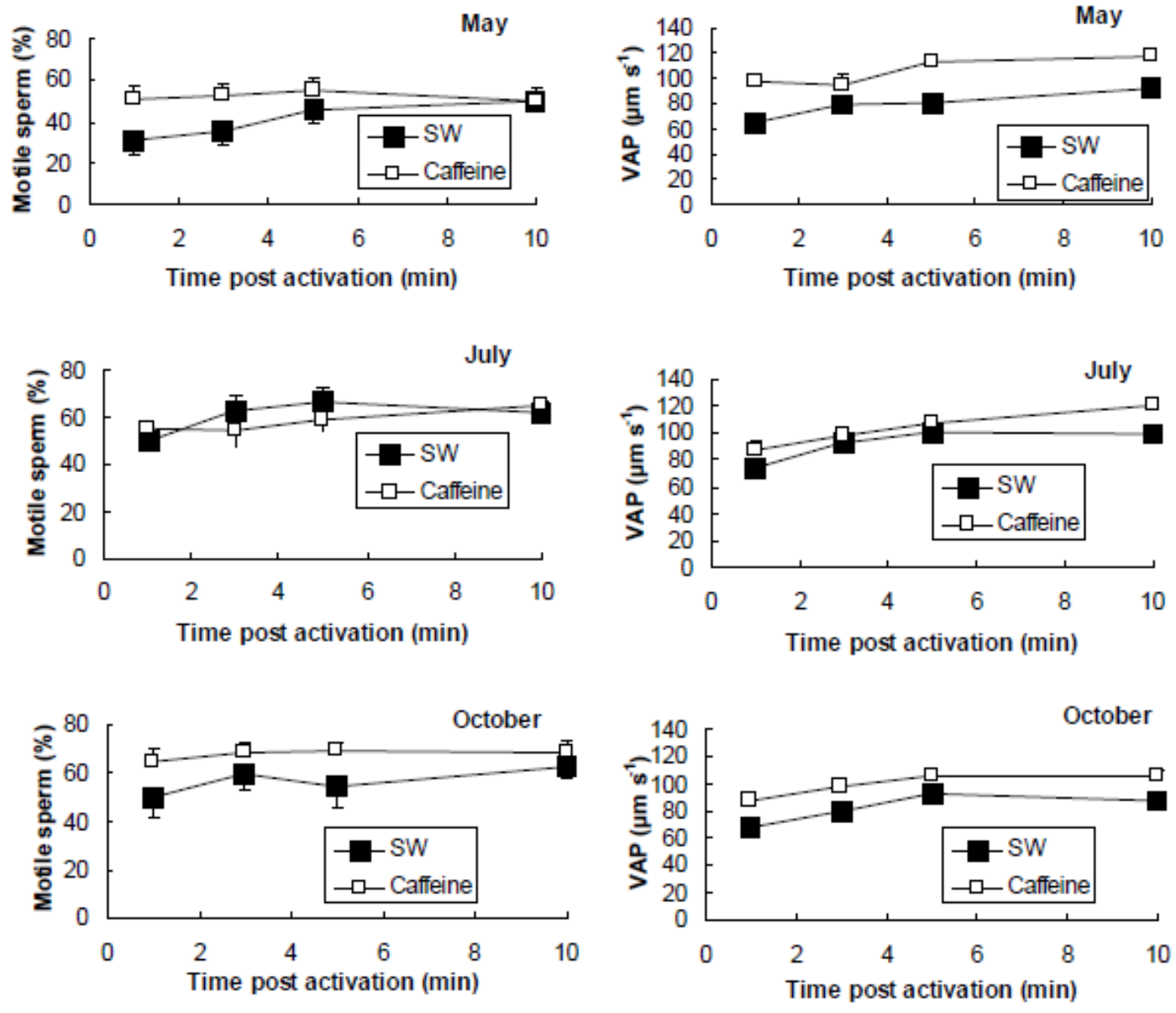

Fig. 1 

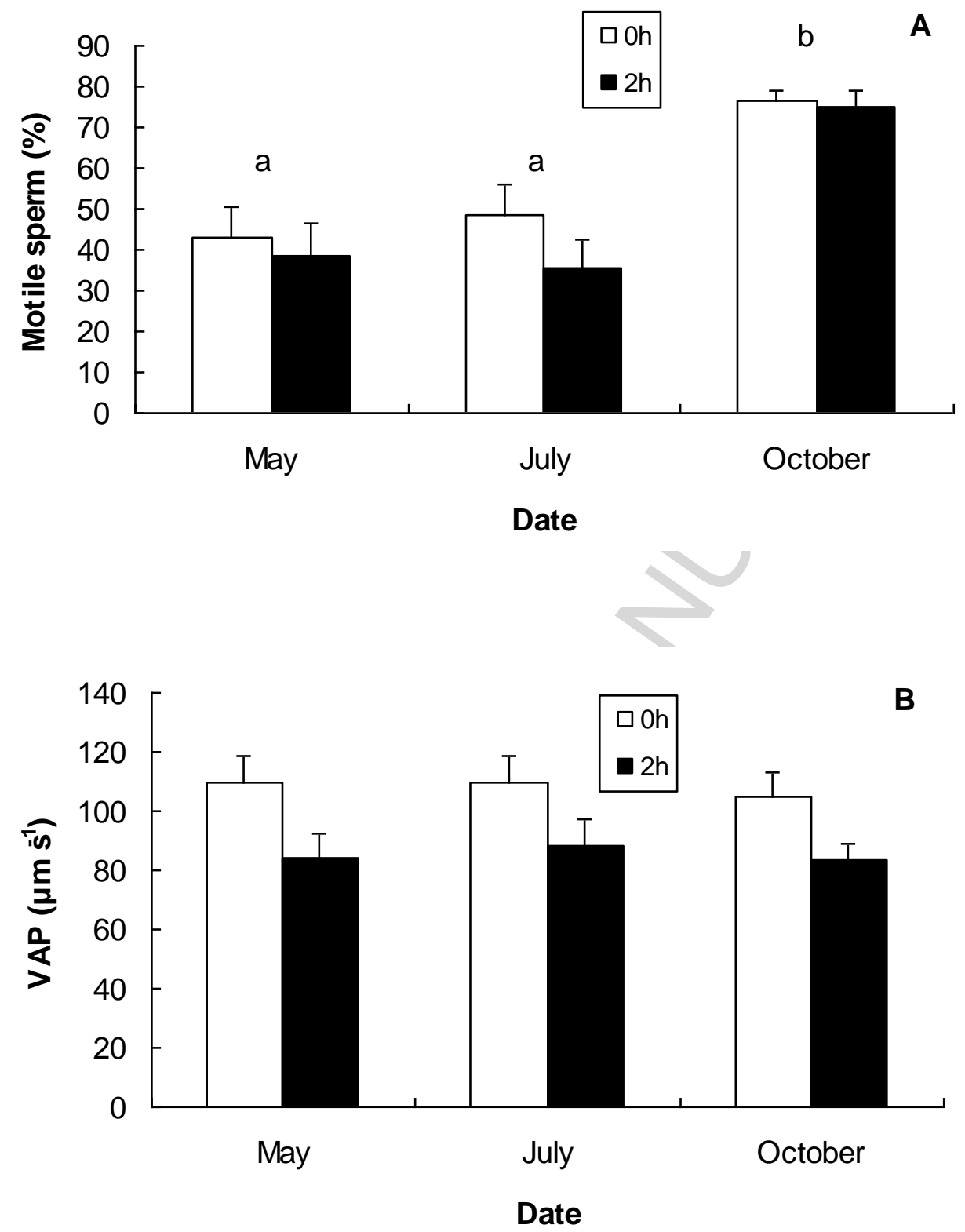

Fig. 2 


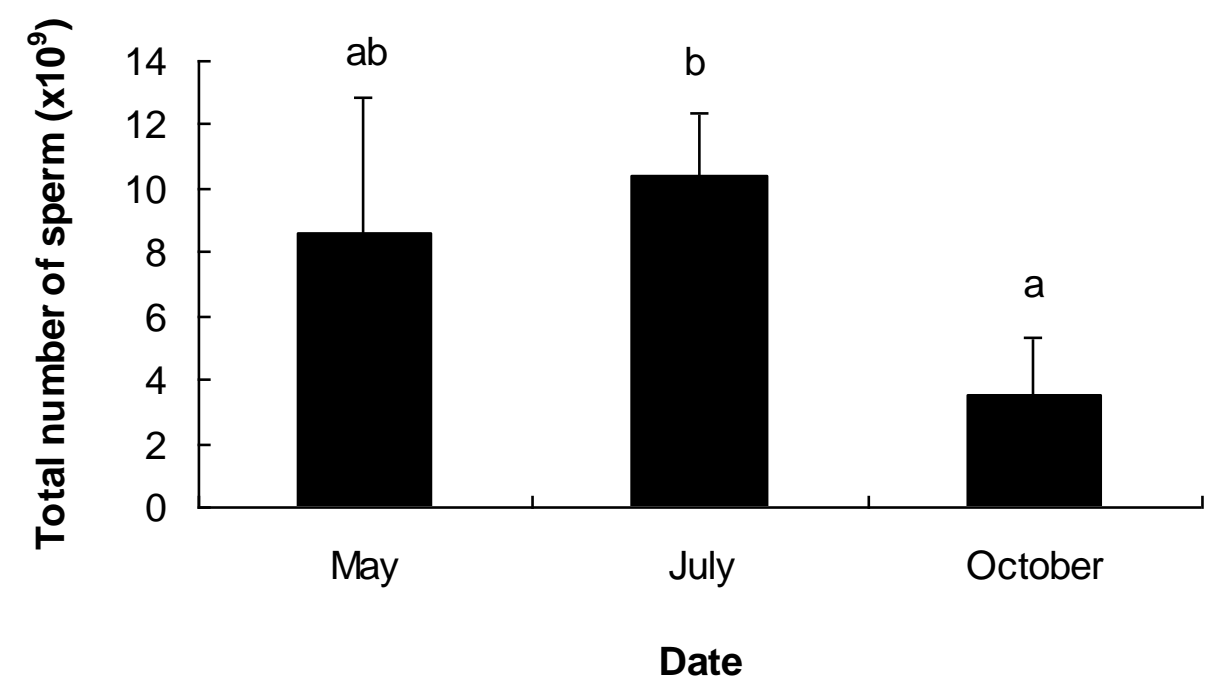

Fig. 3 